\title{
Influence of servant leadership and school organizational culture on the performance of public senior high school teachers in Padang city
}

\author{
Fitrah Santosa ${ }^{1}$, Syamsir ${ }^{2}$, Afriva Khaidir ${ }^{3}$ \\ ${ }^{123}$ Universitas Negeri Padang, Padang - Indonesia, (fitrahsantosa@gmail.com)
}

\begin{abstract}
Teachers have a very important role in the whole process of achieving the goals of national education. Teachers as educators are required to have maximum performance for the purpose of national education can be achieved. The purpose of this study is to look whether servant leadership and school organizational culture simultaneously influence the performance of public senior high school teacher in Padang City. The research method used is associative quantitative method, data analysis used in this research is regression analysis technique. The research method used is associative quantitative method, the population of this research is teachers of State Senior High School in Padang City, with the number of samples is 292 teachers. The results of this study are: servant leadership and school organizational culture simultaneously have a significant effect on teachers performance at Public Senior High School in Padang City.
\end{abstract}

Keywords: Servant leadership, school organizational culture, and teacher performance

\section{Introduction}

Development in the field of education is an important factor that must be done by the state to be able to improve people's welfare and economic development of a country.Development in the education sector is expected to create human resources with good quality, should be able to improve the capability and productivity of human resources performance, so that later can provide maximum results and give effect to the process of economic growth of a country.The quality of education becomes the determinant of the ups and downs of development in a country, right now many countries try to create a national education system that has a good quality as an effort in improving the quality of life of the community. It goes togetherwith the objectives of Indonesian national education listed in Law No. 20 of 2003 about The National Education System article 3,state that the purpose and function of the national education itself is; develop the ability and form the character and civilization of a dignified nation in order to educate the nation's life. Thismeans that the implementation of national education is expected to improve the nation's intelligence level which will affect the economic development in the country.In Indonesia itself, in Act No. 23 of 2014 article 12 (1) about Loval Government, the matter of education is a compulsary affairs that must be held by the government. So, good or bad education implementation by the governance will determine the level of 
intelligence and human resource capabilities owned by the state and will ultimately determine the level of economic and prosperity of the people of that country.

Providing education with good quality at all levels of education, is greatly determined by the principal's leadership. Many research findings explain that there is a strong relationship between professional headmaster leadership and good quality schools. It is impossible that unprofessional headmaster leadership can produce qualified human resources (Hussein Mahmood 2008).

Professional school leadership is the leadership of a principal that capable of using a variety leadership style that can mobilize existing resources so as to improve the performance of all elements of the school in realizing a quality school. There are many different styles of school leadership, ranging from leadership learning by Petterson (1993); Transactional leadership by (Burns 1978; Bass 2007), transformational leadership by (1983, 1983, Bryman 1992; Low \&Gardner 2001; Riggio 2006), authentic leadership by (Robert Terry 1993; Bill George 2003), ethical leadership by ( Aronson 2001; Kanungo 2001; Ciula 2001 \& 2003; Trevino, Brown \& Hartman 2003; Price 2008; Johnson 2011) have been used as the theoretical basis for conducting research on leadership effectiveness and its relation to performance, job satisfaction, organizational culture, organizational and school work climate effective. However, research on leadership that serves has not received much attention from experts, observers and researchers to conduct research on the contribution and influence of leadership that serves in improving the performance of organizations both social organizations and education in Indonesia.

The development of research that focuses on leadership styles continues to grow, and the latest research developments in leadership practice are servant leadership.Servant leadership can be an alternative out of many leadership styles that can be applied in educational institutions, this is because the criteria of servant leadership theory is a human-oriented leader, a leader who cares about self-development, others development and the surrounding environment.Servant leadership model has an influence on the results of individual performance and organizational performance (Northouse, 2013: 219). Servant leadership criteria is also in accordance with the requirements of competence that must be owned by a prospective headmaster according to Minister of Education Regulation no. 13 of 2007 about Headmaster Standards,state that one of the competencies that must be possessed is the ability to innovate of the school development and the abilities to manage the teacher and staffsin order to optimize the utilization of human resources.

Servant leadership as a leadership model, has a principle that prioritizes personal growth of subordinates based on criteria such as teamwork and community development, personal involvement in decision-making processes, and caring and ethical behavior toward subordinates.it is expected that the best form of service from the principal to teachers and education personnel in the school can affect the performance of teachers and education personnel (Asruri, 2016: 8). Based on this, the servant leadership model is suitable and can be one of the leadership methods that can be implemented into educational institutions such as schools, especially schools in the city of Padang.

Beside the style of leadership, other factors that can affect anindividual's performance, especially on the performance of teachersis a school organizational culture. Any organization whether a private or publicinstitutions should have its own characteristics which will form its own organizational culture.Organizational culture in private institutions is definitely different from the organizational culture in public institutions, especially in educational institutions such as schools, even inter-school organizational culture-can be different from each other.organizational culture has an impact on the performance of individuals as members of the organization, as well as against the organization itself (Edison, et al:2016). This also applies to educational institutions such as schools, where school cultures that adopted and implemented by a school will be able to influence the performance of teachers and school staff (Susanto:2016). Organizational culture in schools is not much different from 
the organizational culture in other institutions, the difference lies in the goal, where the educational institutions has a goal in achieving the ideals of national education.

In the process of the national education itself can not be separated from the role of a teacher, Teachers have a very important role in the whole process of achieving good quality education to create good quality human resourcesand teachers have a strategic role in realizing it all through the results of its performance. The low performance of teachers can be one of the factors affecting the quality of our education. From observations made by researchers at several public senior high schools in the city of Padang, it appears that teachersperformance are currently at an unsatisfactory level. Still found some unprofessional actions by some individual teachers such as coming late and coming home when the headmaster is not in place.This of course affects the implementation of national education which will affect the quality of human resources owned by this nation.

Therefore, researchers interested in conducting research on the Influence of Servant Leadership and School Organizational Culture on The Performance of Public Senior High School Teachers in Padang City.

The performance of teachers is the ability shown by the teacher in performing the task or work (Rachmawati \& Daryanto:2013). Teacher performance according to Supardi (2013) is the ability of a teacher in carrying out the task of learning in school / madrasah and responsible for students under the guidance by improving student achievement.To assess the performance of teachers, can be measured through the ability of the teacher. Based on Government Regulation no. 19 of 2005 About National Education Standards article 28 paragraph 3, that as an educator the teacher must have some of the following competencies: (a) pedagogic competence, (b) personality competence, (c) professional competence, and (d) social competence.

The main principle of servant leadership is to prioritize followers, empower them, and help them develop their full personal capacity. The main principle contained in servant leadership is an ethical and lead in a way that serves the larger interests, in the sense of prioritizing the interests of the organization, community, and society in general. Northouse (2013) points out seven behaviors of leaders who serve, 1) Form Concepts, 2) Restore Emotions, 3) Prioritize Followers, 4) Help Followers Grow and Succeed, 5) Behave Ethically, 6) Empower, 7) Create Value for the Community.

Organizational culture can also be interpreted as an existing rules in an organization. Organizational culture in schools can lead to a system of values or beliefs shared by teachers, school staffs, and implemented with full awareness as naturally formed behaviors. With the same understanding of each element of the school it will create a strong and conducive organizational culture in school. Saphier \& King in Susanto (2016), points out 12 characteristics of school organizational culture, they are: 1) Kolegalitas, 2) Experiments, 3) High expextation, 4) Trust and confidence, 5) Tangible support, 6) Reaching out to the knowledge base. 7) Appreciation and recognition, 8) Caring, celebration and humor, 9) Involvement in decision making, 10) Protection of what important, 11) Tradition, 12) Honest, open communication.

\section{Method}

This study uses an associative quantitative approach. This type is chosen because this study aims to reveal how much influence of independent variables on dependent variables, either partial influence or simultaneously (Sugiyono (2012). This research was conducted in Padang City, to 16 Public Senior High Schools. In this study the technique used in data collection is a questionnaire. scale used in this research questionnaire is Likert scale, Likert scale is used to measure matters relating to attitude, opinion and perception of someone to a focus of problem in a research.

The normality test in this study was conducted using Kolmogorov-Smirnov method, is part of the classical assumption test which aims to find out whether the residual value is normally distributed or 
not with the test criteria are: 1) if the significance value $>\alpha$ then the data is normally distributed 2) if the sign value $<\alpha$ then the data is not normally distributed.

Multicollinearity test is done to see whether or not multikolinearity effect among variables, because good regression model is there is no correlation found between independent variables. Multicollinearity test can be seen from the amount of VIF (Variance Inflation Factor) and Tolerance.

Heterocedasticity test is used to test whether there is a variant inequality of the residual of an observation to another observation. A good regression model is homocedasticity or free from symptoms of heterokedastisitas. The way that can be done to test whether or not the situation of heterokedastisitas in the regression model is to look to the scatterplot diagram or do a glejser test on SPSS program. If there is a clear pattern and the point spreads up and below 0 on the $Y$ axis of the scatterplot diagram, there is no heterokedastisity.

Descriptive statistical analysis is used to obtain an overview of the measurements of each variable in this study. While the classification of performance level will be measured and explained based on the following criteria:

Table 1 Classification of Respondents Achievement Level

\begin{tabular}{cc}
\hline Level of Respondents' Achievement (\%) & Criteria \\
$90-100$ & Very Good \\
$80-89$ & Good \\
$65-79$ & Pretty Good \\
$55-65$ & Less Good \\
$1-54$ & Bad \\
\hline
\end{tabular}

And the statisticalF test (simultaneous) is done to determine whether all independent variables in this study have a joint influence on the dependent variable. To examine the mutual influence of servant leadership (X1) variable, and organizational culture (X2) on teacher performance $(\mathrm{Y})$, the researcher will use multiple regression analysis technique

\section{Results and Discussion}

Normality test results in this study indicate there is a significant value (Asymp Sig) of $0.771>0.05$, meaning that the residual value of this study has been distributed normally. While multicolinearity test results showed both independent variables have VIF value $<10$ and Tolerance value $>0,01$, this is in accordance with multicollinearity test criteria, so it can be concluded that there is no multikolinearity between independent variables in this study. The results of heteroscedasticity test using scatterplot are considered very weak because they rely solely on the visual analysis of the researchers themselves. So for the exact value, need to do statistical test that is using test method Glejser. the basis of decision making and interpretation of heterokedasticity test using glejser test are: 1) if Sig above or $>0,05$, hence no heterokedastisitas, 2) if Sig below or $<0,05$, hence heterokedastisitas. After the glejser test, the findings of heterokedasticity test in this study indicate that the significance value of servant leadership variable is $0.512>0.05$ and the significance value of school organizational culture variable is $0.070>0.05$. It can be concluded that there is no effect of heterokedastisitas in this research. 
Descriptive analysis is done in order to get a picture of the measurement of each variable of this study. This study consists of two independent variables and one dependent variable, Servant Leadership (X1), School Organization Culture (X2), and Teacher Performance (Y) variable. All indicators of the three research variables will be tested using descriptive statistical analysis to measure and describe thoroughly the extent to which the level of achievement of respondents to the statement items / questionnaire research that has been spread.

The results of descriptive analysis of teacher performance consist of (1) pedagogic competence, (2) professional competence, (3) social competence, (4) personality competence with 11 items instrument with result of the level of respondents' achievement overallscore is $77,60 \%$, that meanthe performance of high school teachers in the city of Padang is in a pretty good category.The results of the descriptive analysis for servant leadership variables in this study, adopted from the opinion/model proposed by Northouse (2013) consisting of 8 items of instruments with the level of respondents' achievement overallscore is $83.50 \%$, can be interpreted that the application of servant leadership principles by the heads of state high schools in the city of padang already in the good category. Theoverallscore of thelevel of respondents' achievement forschool organizational culturevariables is $85.99 \%$, this means that the organizational culture of state senior high schools in padang city is in the good category.

The $\mathrm{F}$ test is a statistical test conducted to determine whether the two independent variables in this study have a joint influence on the dependent variable.As for the findings for the $\mathrm{F}$ test of this research is:

Table 2.Anova

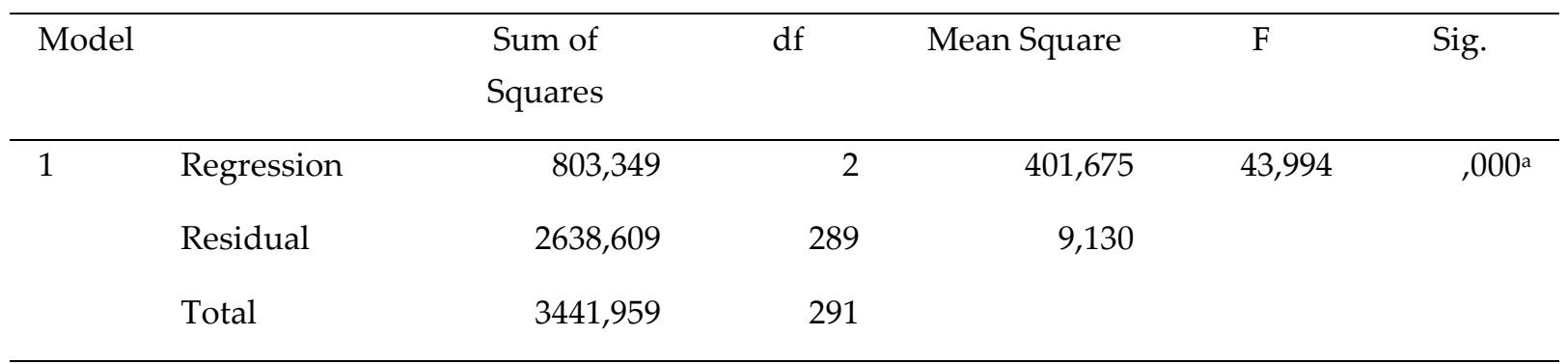

a. Predictors: (Constant), School Organization Culture, Servant Leadership

b. Dependent Variable: Teacher Performance

From table 2, it was found that servant leadership and school organizational culture variables significantly influence teacher performance, with a significance value of 0.000 .

Tabel 3. Model Summary

\begin{tabular}{lrrrrr} 
Model & R & R Square & $\begin{array}{c}\text { Adjusted R } \\
\text { Square }\end{array}$ & $\begin{array}{c}\text { Std. Error of } \\
\text { the Estimate }\end{array}$ & $\begin{array}{c}\text { Durbin- } \\
\text { Watson }\end{array}$ \\
\hline 1 & $4,483^{\mathrm{a}}$ & 233 & 228 & 3,022 & 1,756
\end{tabular}

a. Predictors: (Constant), School Organization Culture, Servant Leadership

b. Dependent Variable: Teacher Performance

From table 3, it was found that both variables simultaneously have a magnitude of influence of $22.8 \%$ on teacher performance in the study sites. 
The Effect of Servant Leadership (X1) and School Organization Culture (X2) on Teacher Performance (Y) State Senior High School in Padang City

Based on the results of F-test, there was a significant effect simultaneously from servant leadership $(\mathrm{X} 1)$ and school organizational culture $(\mathrm{X} 2)$ on teacher performance $(\mathrm{Y})$ with a significance value of 0.000 , and also found adjusted $\mathrm{r}$ square value of 0.228 which means simultaneously the two independent variables of this study have an effect of $22.8 \%$ of the dependent variable (teacher performance) in this research location.

There are many factors that can affect teacher performance, but in this research, the researcher only focuses on two factors, that is servant leadership (X1) and school organization culture (X2). this study proves that teacher performance can be improved through the application of the principles of servant leadership and school organizational culture. In practice, these two factors have an interplay of performance.Leadership and organizational culture have a reciprocal and mutually influential relationship, in the sense that leadership can influence an organizational culture and organizational culture can also influence leadership style.leadership and organizational culture have strong relationships in achieving organizational goals (Edison, et al: 2016). The results of this study can provide a new discourse for the development of leadership practice in educational institutions, especially in state senior high schools.

\section{Conclusions}

Based on the results of statistical tests of this research data, it can be concluded that,there is an influence of servant leadership and school organizational culture simultaneously on the performance of teachers at State Senior High School in Padang City. With a significance value of 0.000 and the magnitude of the simultaneously effect of both independent variables on teacher performance at the research location is $22.8 \%$.

\section{References}

Asruri, Ali. (2016). Servant Leadership Kepala Sekolah Di Sd Negeri 1 Grobogan Kabupaten Grobogan. Tesis. Program Studi Magister Administrasi Pendidikan Sekolah Pascasarjana Universitas Muhammadiyah Surakarta

Mahmood, H. (2008). Kepemimpinan dan keberkesanan sekolah Berjaya.

Law no. 20/2003 About National Education System

Law no. 23/2014 About Local Government

Government Regulation no. 19/2005 About National Education Standards

Minister of Education Regulation no. 13 of 2007 About Principal Standards

Rachmawati, Tutik. Daryanto. (2013). Professional Teacher Performance Assessment and Credit Score. Yogyakarta. Gava Media.

Susanto, Ahmad. (2016). Manajemen Peningkatan Kinerja Guru.Jakarta. Prenada Media Grup

Northouse,Peter G. (2013). Kepemimpinan.Teori dan Praktik, edisi keenam. Jakarta. Indeks.

E. Edison, Y. Anwar, I. Komariyah. (2016). Manajemen Sumber Daya Manusia. Bandung.Alfabeta.

Sugiyono. (2016). Metode Penelitian Kuantitatif, Kualitatif dan R\&D. Bandung. Alfabeta

Supardi. (2013). Kinerja Guru. Jakarta. Rajawali Pers. 